\title{
Evaluation Model of Emergency Evacuation Capacity of Subway Station Based on Grounded Theory
}

\author{
Lianhua Cheng, Yuhang Gao* \\ School of Safety Science and Engineering, Xi'an University of Science and Technology, Xi'an, China \\ Email: *375324451@qq.com
}

How to cite this paper: Cheng, L.H. and Gao, Y.H. (2019) Evaluation Model of Emergency Evacuation Capacity of Subway Station Based on Grounded Theory. World Journal of Engineering and Technology, 7, 27-37.

https://doi.org/10.4236/wjet.2019.72B004

Received: April 4, 2019

Accepted: May 14, 2019

Published: May 17, 2019

\begin{abstract}
In order to evaluate the emergency evacuation capacity of subway stations, the data collected were analyzed based on grounded theory, and an evaluation model of emergency evacuation capacity was constructed by combining the analytic hierarchy process (AHP). Finally, 12 secondary indicators (categories) and 4 primary indicators (main categories) were obtained, among which the primary indicators were management factors, emergency response, construction factors and personnel factors. From the weight value calculated by analytic hierarchy process, we can see that management factors and emergency response have great influence on the emergency evacuation capacity of subway stations. Therefore, we should focus on management factors and emergency response to improve the emergency evacuation capacity of subway stations.
\end{abstract}

\section{Keywords}

Emergency Evacuation Capacity, Analytic Hierarchy Process,

Grounded Theory

\section{Introduction}

At the time the subway brings convenience to the travel of urban residents, due to its mass passenger flow, high density and relatively closed environment, after the emergency, the emergency evacuation will often lead to increased casualties and property losses. The fire incident at the King's Cross subway station in London in the 1980s, the large passenger flow accident in the Belarusian subway station in 1999, and the artificial arson in the Daegu subway in South Korea in 2003 all caused major casualties and property losses. 
The above emergencies were due to the inadequate emergency evacuation capacity, resulting in a sharp increase in the number of casualties and consequences of the accident, which further expanded the seriousness. In order to standardize and improve the emergency evacuation ability for emergencies, to resist the disaster impact of emergencies scientifically and effectively and avoid secondary accidents to reduce casualties, subway stations must have a complete emergency evacuation mechanism for public emergencies, constructing a capability evaluation system that can quickly and efficiently implement subway emergency evacuation. Many scholars have studied the evaluation system of emergency evacuation capacity in order to reduce the risk in the process of evacuation: Li Yiman [1] had extracted three factors which influence the evacuation capacity of the station: passenger flow organization, equipment layout and train operation plan. Based on the analysis results, the evaluation system of subway evacuation capacity had been established. Ma Junjie [2] used the method of fuzzy network analysis to analyze the factors of system equipment, operation management and personnel evacuation, and established the evaluation index system of emergency evacuation capability of subway operation system. Ding Xiaoqing [3] analyzed the influencing factors of emergency evacuation capacity of Subway stations, and built an evaluation index system of emergency evacuation capacity of subway stations based on queuing network model.

The above researches provide reference for subway emergency evacuation capability evaluation from different aspects, and have guidance and reference significance for subway emergency evacuation. The construction of index system is based on theoretical assumptions beforehand, and then builds layers according to the assumptions. Since the evaluation system is constructed from the pre-theoretical hypothesis, it will inevitably be limited to subjective hypothesis, which makes the evaluation system not comprehensive and objective. Therefore, how to build a comprehensive, reliable and practical emergency evacuation capacity evaluation index system is a problem that needs to be solved at present. Based on the grounded theory [4], this paper abandons the pre-hypothesis theory, through a large number of data collection and comparative analysis, constructs the evaluation index system from bottom to top, which has practical basis. At the same time, the 1 - 9 scale method of Saaty [5] is used to construct a judgment matrix and a more comprehensive quantitative index system model for evaluating the emergency evacuation capacity of subway stations, which can provide scientific decision support for the emergency evacuation of subway stations.

\section{Research Method and Process}

\subsection{Research Method}

The grounded theory method is a qualitative research method proposed by Glaser in 1967 [6]. This method requires researchers to first abandon the previous theoretical hypothesis, then conduct a large amount of data collection on 
the research objectives, next analyze the data and gradually summarize and finally build the theory layer by layer. Grounded theory is widely used to explore and generalize the cause of a phenomenon because of its flexibility, systemicity and effectiveness. Its greatest feature is data analysis while data collection. For the evaluation index system, the grounded theory is to construct indicators at all levels from the summary of the original data, which is the "bottom-up" induction deduction rather than constructing the indicator system from the expected logical deduction. The inductive interpretation of grounded theory consists of four steps: open coding, spindle coding, selection coding, and theoretical saturation testing. This study uses the above four steps to build a subway emergency evacuation capacity evaluation index system.

\subsection{Data Collection}

In order to ensure the completeness of the indicator system, extensive research, and multi-faceted data collection, the data acquisition objects are first determined. The data collection objects include: 1) Personnel interview: 5 environmental control dispatchers, who continue to pay attention to the operation of the station fire safety equipment. In the case, there is a deep understanding of the fire hazard; 5 equipment maintenance dispatchers, who are responsible for receiving, transmitting and feedback information on facility equipment failures, organizing and coordinating general facility equipment failures, and conducting statistics and analysis for evacuation There is a comprehensive understanding of the failure of the facility; there are 6 security officers on the platform. They are mainly responsible for the safety of the passengers on the platform, maintaining the order of the platform, handling passenger problems in a timely manner, conducting inspections, reporting hidden dangers, and properly guiding and organizing passengers during evacuation. Therefore, they have a deep understanding of the various hidden dangers in the evacuation process. 2) National policies and papers: We have analyzed more than 30 articles on the construction of the subway emergency evacuation indicator system, such as the "Safety Evacuation Standards for Subways" and other documents. 3) Accident case: Analysis of domestic and international subway accident cases in the past 20 years. By collecting and removing data with a frequency less than 2 and contradictory data, 147 interview data statements and 74 original text data statements were finally obtained. Those collected data codes were scrambled, and $20 \%$ of them were retained for theoretical saturation test.

\section{Construction of Evaluation Index System}

\subsection{Open Coding}

Opening coding is the basis of grounded theory. This step includes disrupting all raw data, reading and analyzing the data repeatedly. Then, the concept is applied to continuously refine the original data and re-integrate the original data [7]. In the process of coding, all the presupposed concepts should be thrown in the 
mind. It is necessary to maintain an open-minded attitude and analyze the raw data and data word by word to obtain the category and concept closest to the nature of the data. This study focuses on the evaluation of emergency evacuation capability. Based on manual coding, the collected data are recombined and converged, and finally 31 concepts and 12 categories are formed. An example of open coding is shown in Table 1.

\subsection{Spindle Coding}

The purpose of spindle coding is to focus and integrate data, classify the categories obtained after open coding, discover and establish potential logical relationships among categories, and rearrange and classify them. At this stage, further analysis of categories is needed to explore whether there is a potential logical relationship between categories, in order to further condense the higher level of the main category [8]. Common logical relationships are: structural relationship, functional relationship, causal relationship and so on. For example, "staff management", "daily management" and "emergency evacuation management" are all the specific factors involved in the management of subway stations. Therefore, "management factors" are the main categories of these three categories. By analyzing and categorizing the categories of open coding, four main categories are finally obtained: management factors, emergency response, environmental factors and personnel factors, as shown in Table 2.

\subsection{Selection Coding}

Selective coding is based on the spindle coding. Its purpose is to systematically analyze the potential logical relationship between categories and select a core category. In this stage, we need to excavate a core category in the main category, analyze the logical relationship between the core category and the main category, and summarize the related categories into the framework of the evaluation system [9]. Through the spindle coding analysis of the four main categories and the comparative analysis of the raw data, it is finally found that most categories and concepts can be generalized and analyzed by the category of "Evaluation index system of emergency evacuation capability". Therefore, it is defined as the core category, and the evaluation index system of emergency evacuation capacity is finally obtained as shown in Figure 1

\subsection{Theoretical Saturation Test}

The $20 \%$ original data used for saturation test are analyzed by open coding, spindle coding and selective coding again. The final results include all theoretical directions of the core category of "Evaluation index system of emergency evacuation capability", and no new main categories and relationships are found. Therefore, it is considered that the evaluation index system of subway emergency evacuation capability constructed in this paper achieves saturation theoretically. 
Table 1. Open code of subway emergency evacuation capacity evaluation index (representative contents).

\begin{tabular}{|c|c|c|}
\hline category & concept & Raw data \\
\hline \multirow[b]{2}{*}{ Staff management } & Staff training & $\begin{array}{l}\text { A33 I don't know much about some applause } \\
\text { systems, and I don't know how to implement them. }\end{array}$ \\
\hline & Staff assessment & $\begin{array}{l}\text { A101 Employee assessment can know the level of } \\
\text { employee safety knowledge and improve employee } \\
\text { safety skills. }\end{array}$ \\
\hline \multirow{6}{*}{ Daily management } & $\begin{array}{l}\text { Risk classification } \\
\text { control }\end{array}$ & $\begin{array}{l}\text { A02 For industries prone to major accidents, } \\
\text { double preventive working mechanisms should be } \\
\text { adopted, i.e. risk classification control, hidden } \\
\text { danger investigation and treatment. }\end{array}$ \\
\hline & & A71 Eye-catching emergency evacuation \\
\hline & Publicity of emergency & knowledge slogans can help passengers \\
\hline & evacuation knowledge & $\begin{array}{l}\text { understand the correct evacuation steps and } \\
\text { improve evacuation efficiency and safety. }\end{array}$ \\
\hline & $\begin{array}{l}\text { Emergency simulation } \\
\text { exercise }\end{array}$ & $\begin{array}{l}\text { A16 Emergency simulation exercises can help me } \\
\text { better understand my role in emergency } \\
\text { evacuation }\end{array}$ \\
\hline & $\begin{array}{l}\text { Implementation of } \\
\text { management system }\end{array}$ & $\begin{array}{l}\text { A117 It is necessary to confirm the } \\
\text { implementation of the Subway Management } \\
\text { System in order to avoid the tragedy caused by } \\
\text { non-compliance with the system. }\end{array}$ \\
\hline \multirow{3}{*}{$\begin{array}{l}\text { Emergency } \\
\text { evacuation } \\
\text { management }\end{array}$} & $\begin{array}{l}\text { Effectiveness of } \\
\text { emergency plan }\end{array}$ & $\begin{array}{l}\text { A47 Whether the preparation of emergency plan is } \\
\text { reasonable and whether it can play the greatest role } \\
\text { in the process of emergency evacuation is the key } \\
\text { to emergency evacuation. }\end{array}$ \\
\hline & $\begin{array}{l}\text { Establishment of } \\
\text { emergency evacuation } \\
\text { organization }\end{array}$ & $\begin{array}{l}\text { A123 The rational allocation of emergency } \\
\text { evacuation organization personnel includes } \\
\text { whether the division of functions of the } \\
\text { organization personnel is clear, and whether the } \\
\text { division of functions of the organization personnel } \\
\text { is reasonable is the premise of successful } \\
\text { evacuation. }\end{array}$ \\
\hline & $\begin{array}{l}\text { Emergency evacuation } \\
\text { resource allocation }\end{array}$ & $\begin{array}{l}\text { A159 The rational allocation of emergency } \\
\text { evacuation resources provides a solid foundation } \\
\text { for emergency evacuation work }\end{array}$ \\
\hline \multirow{2}{*}{$\begin{array}{l}\text { Employee emergency } \\
\text { response ability }\end{array}$} & $\begin{array}{l}\text { Rapid response } \\
\text { capability }\end{array}$ & $\begin{array}{l}\text { A103 Response should be made in the first time } \\
\text { after the accident happened, and the time for } \\
\text { rescue and evacuation should be strived for. }\end{array}$ \\
\hline & $\begin{array}{l}\text { Field command } \\
\text { capability }\end{array}$ & $\begin{array}{l}\text { A27 In the process of emergency evacuation, } \\
\text { managers' on-site command ability is the key to } \\
\text { successful evacuation. }\end{array}$ \\
\hline \multirow{3}{*}{ Fire control level } & $\begin{array}{l}\text { Automatic sprinkler } \\
\text { system }\end{array}$ & $\begin{array}{l}\text { A13 After the fire accident in Daegu Subway, } \\
\text { South Korea, there was no automatic sprinkler } \\
\text { system in the carriage, which led to the rapid } \\
\text { spread of the fire and heavy casualties. }\end{array}$ \\
\hline & $\begin{array}{l}\text { Fire extinguishing } \\
\text { facilities }\end{array}$ & $\begin{array}{l}\text { A137 Fire extinguisher is an important equipment } \\
\text { for controlling fire spread and eliminating fire } \\
\text { when a fire occurs in a subway station. }\end{array}$ \\
\hline & $\begin{array}{l}\text { Ventilation and smoke } \\
\text { exhaust system }\end{array}$ & $\begin{array}{l}\text { A121 When a fire occurs, the ventilation and } \\
\text { smoke exhaust system can continuously discharge } \\
\text { the smoke, reduce the harm of toxic gases to } \\
\text { evacuation, increase visibility and reduce the risk } \\
\text { in the process of evacuation. }\end{array}$ \\
\hline
\end{tabular}




\section{Continued}

\begin{tabular}{|c|c|c|}
\hline \multirow[t]{2}{*}{ Fire control level } & $\begin{array}{l}\text { Automatic fire alarm } \\
\text { system }\end{array}$ & $\begin{array}{l}\text { A48 When a fire occurs, the automatic alarm } \\
\text { system can promptly remind the station personnel } \\
\text { to prepare for evacuation and reduce evacuation } \\
\text { time. }\end{array}$ \\
\hline & $\begin{array}{l}\text { Emergency lighting } \\
\text { facilities }\end{array}$ & $\begin{array}{l}\text { A57 South Korea Daegu Subway Fire Accident, } \\
\text { Subway Station blackened after power failure, } \\
\text { emergency lighting facilities and exit guiding } \\
\text { lights did not light up }\end{array}$ \\
\hline \multirow[t]{2}{*}{$\begin{array}{l}\text { Emergency assistance } \\
\text { facilities }\end{array}$} & Evacuation instruction & $\begin{array}{l}\text { A20 Evacuation signs can make passengers clear } \\
\text { evacuation routes and make my command and } \\
\text { management in evacuation more smoothly and } \\
\text { smoothly. }\end{array}$ \\
\hline & Broadcasting system & $\begin{array}{l}\text { A07 The broadcast announcement during } \\
\text { evacuation can help me to know more about the } \\
\text { next work, and also let passengers know the } \\
\text { accident situation and prepare for evacuation } \\
\text { quickly. }\end{array}$ \\
\hline \multirow{2}{*}{ Stairs/escalators } & $\begin{array}{l}\text { Number of } \\
\text { stairs/escalators }\end{array}$ & $\begin{array}{l}\text { A66 Stairs/escalators are the first areas where } \\
\text { people are blocked during evacuation. The number } \\
\text { of stairs/escalators will directly affect emergency } \\
\text { evacuation. }\end{array}$ \\
\hline & $\begin{array}{c}\text { Width of } \\
\text { stair/escalator }\end{array}$ & $\begin{array}{l}\text { A77 The minimum width of one-way stairs and } \\
\text { two-way stairs in subway station is } 1.8 \mathrm{~m} \text { and } 2.4 \\
\mathrm{~m} \text { respectively. The minimum width of stairs } \\
\text { arranged side by side with escalators is } 1.2 \mathrm{~m} \text {. }\end{array}$ \\
\hline \multirow{2}{*}{ Automatic fare gate } & $\begin{array}{l}\text { Number of automatic } \\
\text { fare gate }\end{array}$ & $\begin{array}{l}\text { A71 The gate is narrow and can only be evacuated } \\
\text { by one person at a time, so the design of the } \\
\text { number of gates must meet the evacuation time. }\end{array}$ \\
\hline & $\begin{array}{c}\text { Type of automatic fare } \\
\text { gate }\end{array}$ & $\begin{array}{l}\text { A } 86 \text { The maximum throughput of the three-bar } \\
\text { gate is } 20 \text { persons } / \mathrm{min} \text {, and that of the threshold } \\
\text { gate is } 30 \text { persons } / \mathrm{min} \text {. }\end{array}$ \\
\hline \multirow{4}{*}{$\begin{array}{l}\text { Passenger flow } \\
\text { characteristics }\end{array}$} & Number of exit & $\begin{array}{l}\text { A39 The number of entrances and exits to each } \\
\text { floor in each public area shall not be less than } 2\end{array}$ \\
\hline & Width of exit & $\begin{array}{l}\text { A28 The width of each entrance and exit shall be } \\
\text { determined by multiplying } 1.1-1.25 \text { non-uniform } \\
\text { coefficient of the directional design passenger flow } \\
\text { in the forward or passenger flow control period. }\end{array}$ \\
\hline & $\begin{array}{l}\text { Passenger flow } \\
\text { distribution }\end{array}$ & $\begin{array}{l}\text { A155 Every time I stand on the platform, I remind } \\
\text { passengers to walk in the middle and not to gather } \\
\text { at the doors near the stairway entrance. }\end{array}$ \\
\hline & Passenger flow density & $\begin{array}{l}\text { A136 Every morning rush and evening rush hour I } \\
\text { work a lot because there are so many people. }\end{array}$ \\
\hline \multirow{2}{*}{$\begin{array}{l}\text { Passenger's } \\
\text { non-adaptive } \\
\text { Behavior }\end{array}$} & Herd behavior & $\begin{array}{l}\text { A106 During the evacuation process, passengers } \\
\text { tend to go to crowded places. I must guide the flow } \\
\text { of passengers so that the number of passengers } \\
\text { evacuated at each exit is equal. }\end{array}$ \\
\hline & Reentry behavior & $\begin{array}{l}\text { A97 In the process of evacuation, individual } \\
\text { passengers will turn back for searching due to the } \\
\text { loss of goods and other reasons, resulting in } \\
\text { conflict and blockage of human flow. }\end{array}$ \\
\hline
\end{tabular}




\section{Continued}

\begin{tabular}{|c|c|c|}
\hline & Panic behavior & $\begin{array}{l}\text { A41 In the evacuation process, our most worrying } \\
\text { situation is that the passengers are in a panic } \\
\text { disorder and lose their reason, which can easily } \\
\text { lead to trampling and other secondary accidents. }\end{array}$ \\
\hline \multirow[t]{2}{*}{ Staff quality } & $\begin{array}{l}\text { Self-protection } \\
\text { consciousness }\end{array}$ & $\begin{array}{l}\text { A08 Subway employees should also protect their } \\
\text { own safety in the process of commanding } \\
\text { evacuation. }\end{array}$ \\
\hline & Violation of regulations & $\begin{array}{l}\text { A34 The root cause of most subway casualties is } \\
\text { carelessness and violation of rules and regulations. }\end{array}$ \\
\hline
\end{tabular}

Table 2. Main categories of spindle coding formation for subway emergency evacuation capacity evaluation index.

\begin{tabular}{|c|c|c|}
\hline Main category & Corresponding category & Category connotation \\
\hline \multirow{3}{*}{ Management factors } & Staff management & $\begin{array}{l}\text { Staff training and staff assessment can make } \\
\text { the work more standardized and safe. }\end{array}$ \\
\hline & Daily management & $\begin{array}{l}\text { To ensure the normal functioning of the } \\
\text { management area and identify risk factors }\end{array}$ \\
\hline & $\begin{array}{l}\text { Emergency evacuation } \\
\text { management }\end{array}$ & $\begin{array}{l}\text { Based on emergency plan, it is the key to } \\
\text { successful evacuation. }\end{array}$ \\
\hline \multirow{3}{*}{ Emergency response } & $\begin{array}{l}\text { Employee emergency } \\
\text { response ability }\end{array}$ & $\begin{array}{l}\text { Employee emergency response ability can buy } \\
\text { valuable time for emergency evacuation. }\end{array}$ \\
\hline & Fire control level & $\begin{array}{l}\text { Fire and smoke control facilities will change } \\
\text { the fire development process and strive for } \\
\text { evacuation time. }\end{array}$ \\
\hline & $\begin{array}{l}\text { Emergency assistance } \\
\text { facilities }\end{array}$ & $\begin{array}{l}\text { Important facilities for guiding passengers to } \\
\text { evacuate smoothly during evacuation. }\end{array}$ \\
\hline \multirow{3}{*}{ Architectural factors } & Stairs/escalators & $\begin{array}{l}\text { Where congestion first occurs during } \\
\text { evacuation. }\end{array}$ \\
\hline & Automatic fare gate & Width is small and can easily lead to blocking. \\
\hline & Exit & $\begin{array}{l}\text { The key to successful evacuation is the direct } \\
\text { access of the subway to the outside world. }\end{array}$ \\
\hline \multirow{3}{*}{ Personnel factors } & Passenger flow characteristics & $\begin{array}{l}\text { High density and uneven distribution affect } \\
\text { evacuation process. }\end{array}$ \\
\hline & $\begin{array}{l}\text { Passenger's non-adaptive } \\
\text { behavior }\end{array}$ & $\begin{array}{l}\text { It is easy to cause secondary accidents such as } \\
\text { trampling. }\end{array}$ \\
\hline & Staff quality & $\begin{array}{l}\text { Determine the performance of employees in } \\
\text { emergency rescue, directly determine whether } \\
\text { the evacuation is successful or not. }\end{array}$ \\
\hline
\end{tabular}

\section{Construction of Evaluation Model Based on AHP}

The hierarchical structure of the emergency evacuation capability evaluation index system reflects the relationship among various factors, but the proportions of the criteria in the criterion layer are not necessarily the same in the target measurement. In the minds of policy makers, they each have a certain proportion. When determining the proportion of an influencing factor in this factor, the main difficulty encountered is that these proportions are often not easily quantified. AHP uses experience to judge the importance of quantifying indicators, 


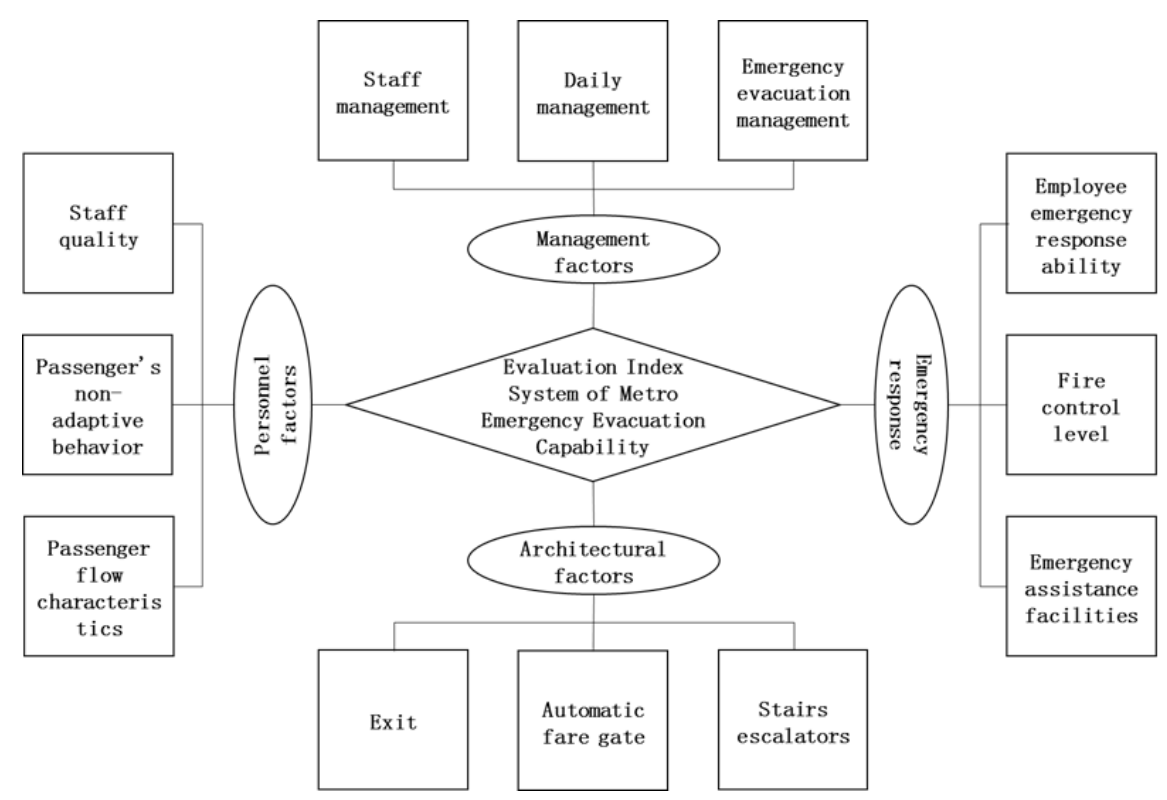

Figure 1. Evaluation index system of emergency evacuation capability.

and obtains the weight of different criteria for each index [10]. According to the weight, the importance of different indicators can be ranked. This method can quantify the indicators at different levels. Therefore, this paper uses 9 importance levels and their assignment given by Saaty to construct the judgment matrix of each level index, and uses AHP analysis to determine the reliable weight of each factor in the evaluation index system.

\subsection{Index Weight Calculation and Consistency Test}

The index system in Chapter 3.3 is coded. The first-level index management factors, emergency response, building factors and personnel factors are B1-B4 from left to right. Secondary indicators from left to right are C1 C12. Delphi analysis and expert questionnaires were synthesized, and the expert data were processed by the number of quartiles. The evaluation index judgment matrix was obtained, and the weight of each index was calculated by MATLAB programming shown in Table 3 and Table 4.

By summarizing the above data, we can get the quantitative evaluation index table of emergency evacuation capacity of Subway emergencies shown in Table 5.

\subsection{Result Analysis}

Through the evaluation index system of emergency evacuation capacity of subway, it can be seen that:

1) At the first level of the subway emergency evacuation capacity evaluation index system, the weight of management factors and emergency response is the largest, which shows that management factors and emergency response have the greatest impact on emergency evacuation. Therefore, we should focus on the 
Table 3. Judgment matrix and weight of first-level indicators of subway emergency evacuation capacity.

\begin{tabular}{ccccccc}
\hline & $\mathrm{B}_{1}$ & $\mathrm{~B}_{2}$ & $\mathrm{~B}_{3}$ & $\mathrm{~B}_{4}$ & $\mathrm{~W}$ & $\mathrm{CR}$ \\
\hline $\mathrm{B}_{1}$ & 1 & 1 & 3 & 2 & 0.278 & \\
$\mathrm{~B}_{2}$ & 1 & 1 & 3 & 2 & 0.278 & $0.004<0.1$ \\
$\mathrm{~B}_{3}$ & $1 / 3$ & $1 / 3$ & 1 & $1 / 2$ & 0.204 & adopt \\
$\mathrm{B}_{4}$ & $1 / 2$ & $1 / 2$ & 2 & 1 & 0.240 & \\
\hline
\end{tabular}

Table 4. Judgment matrix and weight of secondary indicators of subway emergency evacuation capability.

\begin{tabular}{cccccccccccc}
\hline $\mathrm{B}_{1}$ & $\mathrm{C}_{1}$ & $\mathrm{C}_{2}$ & $\mathrm{C}_{3}$ & $\mathrm{~W}$ & $\mathrm{CR}$ & $\mathrm{B}_{2}$ & $\mathrm{C}_{4}$ & $\mathrm{C}_{5}$ & $\mathrm{C}_{6}$ & $\mathrm{~W}$ & $\mathrm{CR}$ \\
\hline $\mathrm{C}_{1}$ & 1 & $1 / 2$ & $1 / 3$ & 0.163 & & $\mathrm{C}_{4}$ & 1 & 3 & 3 & 0.594 & \\
$\mathrm{C}_{2}$ & 2 & 1 & $1 / 2$ & 0.297 & $\begin{array}{c}0.009<0.1 \\
\text { adopt }\end{array}$ & $\mathrm{C}_{5}$ & $1 / 3$ & 1 & 2 & 0.249 & $0.051<0.1$ \\
$\mathrm{C}_{3}$ & 3 & 2 & 1 & 0.540 & & $\mathrm{C}_{6}$ & $1 / 3$ & $1 / 2$ & 1 & 0.157 & adopt \\
$\mathrm{B}_{3}$ & $\mathrm{C}_{7}$ & $\mathrm{C}_{8}$ & $\mathrm{C}_{9}$ & $\mathrm{~W}$ & $\mathrm{CR}$ & $\mathrm{B}_{4}$ & $\mathrm{C}_{10}$ & $\mathrm{C}_{11}$ & $\mathrm{C}_{12}$ & $\mathrm{~W}$ & $\mathrm{CR}$ \\
$\mathrm{C}_{7}$ & 1 & 4 & 3 & 0.625 & & $\mathrm{C}_{10}$ & 1 & $1 / 4$ & $1 / 3$ & 0.117 & \\
$\mathrm{C}_{8}$ & $1 / 4$ & 1 & $1 / 2$ & 0.137 & $0.024<0.1$ & $\mathrm{C}_{11}$ & 4 & 1 & 3 & 0.614 & $0.070<0.1$ \\
$\mathrm{C}_{9}$ & $1 / 3$ & 2 & 1 & 0.238 & & $\mathrm{C}_{12}$ & 3 & $1 / 3$ & 1 & 0.269 & adopt \\
\hline
\end{tabular}

Table 5. Quantitative tables of evaluation indicators for emergency evacuation capacity of subway.

\begin{tabular}{|c|c|c|c|c|}
\hline Target layer & First level index & Weight & Second level index & Weight \\
\hline \multirow{12}{*}{$\begin{array}{c}\text { Evaluation Index } \\
\text { of Emergency } \\
\text { Evacuation } \\
\text { Capacity of } \\
\text { Subway }\end{array}$} & \multirow{3}{*}{ Management factors $B_{1}$} & \multirow{3}{*}{0.278} & Staff management $\mathrm{C}_{1}$ & 0.163 \\
\hline & & & Daily management $\mathrm{C}_{2}$ & 0.297 \\
\hline & & & $\begin{array}{c}\text { Emergency evacuation } \\
\text { management } C_{3}\end{array}$ & 0.540 \\
\hline & \multirow{3}{*}{ Emergency response $\mathrm{B}_{2}$} & \multirow{3}{*}{0.278} & $\begin{array}{l}\text { Employee emergency } \\
\text { response ability } \mathrm{C}_{4}\end{array}$ & 0.594 \\
\hline & & & Fire control level $\mathrm{C}_{5}$ & 0.249 \\
\hline & & & Emergency assistance facilities $\mathrm{C}_{6}$ & 0.157 \\
\hline & \multirow{3}{*}{ Architectural factors $\mathrm{B}_{3}$} & \multirow{3}{*}{0.204} & Stairs/escalators $\mathrm{C}_{7}$ & 0.625 \\
\hline & & & Automatic fare gate $C_{8}$ & 0.137 \\
\hline & & & Exit $\mathrm{C}_{9}$ & 0.238 \\
\hline & \multirow{3}{*}{ Personnel factors $\mathrm{B}_{4}$} & \multirow{3}{*}{0.240} & Passenger flow characteristics $C_{10}$ & 0.117 \\
\hline & & & $\begin{array}{c}\text { Passenger's non-adaptive } \\
\text { behavior } \mathrm{C}_{11}\end{array}$ & 0.614 \\
\hline & & & Staff quality $\mathrm{C}_{12}$ & 0.269 \\
\hline
\end{tabular}

management factors and emergency response, reduce the risk and improve the emergency evacuation capacity. Among them, the weight of emergency evacuation management is 0.540 , and the weight of staff's emergency capacity is 0.594 . 
Therefore, improving emergency evacuation management and improving staff's emergency evacuation capacity are the key to successful evacuation.

2) Among the construction factors, the weight of the stairs/elevator is the largest, and the stairs are the most likely to be blocked during the evacuation process, which is the main bottleneck in the evacuation process. In order to reduce the risk in the evacuation process, attention should be paid to the evacuation of personnel at the stairs/elevator, and the work of uniform diversion should be done well.

3) Among the personnel factors, the weight of passenger's non-adaptive behavior is the largest. In subway evacuation, passenger's non-adaptive behavior often causes secondary accidents, such as trampling, resulting in serious casualties and property losses. Therefore, in the actual evacuation work, we should focus on the abnormal behavior of passengers, calm the mood, reduce the risk, and improve the emergency evacuation capacity of the subway.

\section{Conclusions}

1) Based on the grounded theory, through open coding, spindle coding, selective coding and theoretical saturation test, the evaluation index system of emergency evacuation capacity of subway stations is constructed.

2) Applying Saaty's 1 - 9 scale method to construct the judgment matrix of emergency evacuation capacity evaluation, and combining with consistency analysis, the quantitative table of evaluation index of emergency evacuation capacity of subway station is constructed.

3) The AHP analysis shows that the evaluation index model can be used to evaluate the emergency evacuation capacity of Subway stations, and can accurately reflect the existing problems through the evaluation results. It provides a directional basis for the improvement of the emergency evacuation capacity of Subway stations, and reflects the systematicness and operability of the evaluation index system.

\section{Fund Project}

Shaanxi Provincial Key Research and Development Program (2017ZDXMGY-107).

\section{Conflicts of Interest}

The authors declare no conflicts of interest regarding the publication of this paper.

\section{References}

[1] Li, Y.M. (2018) Study on Evaluation of Beijing Subway Dredge Capacity During Mass Passenger Flow.

[2] Ma, J.J. (2014) Comprehensive Evaluation of Emergency Evacuation Capability of Subway Station Based on Fuzzy Network Analysis. Chinese \& Foreign Entrepre- 
neurs, No. 4, 194-196.

[3] Ding, X.Q. (2016) Study on Evacuation Capability of Subway Station Based on Queuing Network Model and Pedestrian Simulation.

[4] Xu, B.G., Hu, Q. and Zhu, J.X. (2018) Study on Impact Factors of Enterprise Intensive Land-Use Behavior: From the Perspective of Grounded Theory. China Land Science, 32, 81-87.

[5] Guo, J.Y. Zhang, Z.B. and Sun, Q.Y. (2008) Study and Application of Analytic Hierarchy Process. Chin Saf Sci J, 18, 148-153.

[6] Glaser, B. and Strauss, A.L. (1968) The Discovery of Grounded Theory: Strategies for Qualitative Research. Nursing Research, 17, 377-380. https://doi.org/10.1097/00006199-196807000-00014

[7] Yan, S.M. and Yang, X.L. (2019) Research on Innovation Power of University Scientific Researchers Based on Grounded Theory. Science and Technology Management Research, 39, 39-45.

[8] Yu, M.X., Wang, L.X. and Yuan, L. (2019) Analysis of Influencing Factors of Land Withdrawal in Mining Areas Based on Grounded Theory. Scientific Decision-Making, No. 1.

[9] Pandit, N.R. (1996) The Creation of Theory: A Recent Application of the Grounded Theory Method. Qualitative Report, No. 4, 1-15.

[10] Wang, F.H., Wang, S.J. and Su, L. (2016) Selection Scheme of Electrochemical Energy Storage Based on Interval AHP. High Voltage Engineering, 42. 